\title{
The transport infraestructure contribution to the urban legacy of the Beijing Olympic Games
}

\author{
A contribuição da infraestrutura de transporte para o legado urbanístico dos \\ Jogos Olímpicos em Beijing, China
}

Yumi Yamawaki[a] (D), Juliana Tomaz[b] (D)

[a] Universidade Tecnológica Federal do Paraná, Curitiba, PR, Brasil

[b] Unibrasil, Curitiba, PR, Brasil

How to cite: Yamawaki, Y., \& Tomaz, J. (2019). The transport infraestructure contribution to the urban legacy of the Beijing Olympic Games. urbe. Revista Brasileira de Gestão Urbana, 11, e20180044. https://doi.org/10.1590/21753369.011.e20180044

\begin{abstract}
When a host city is chosen for the Olympic Games, its visibility on the international stage is increased and it becomes the focus for investments. Urban interventions that can accelerate the implementation of previously drawn up plans or redirect the urban planning process are performed. However, most discussions about the legacy of major sporting events take place without any empirical studies. This study seeks to analyze the planning proposals presented in Beijing, China, and the process by which they were physically implemented in the city. An indirect analysis methodology was carried out based on aerial images to establish a temporal comparison of the physical configurations in the vicinities of the urban railway structures. In this way, identify different dynamics in the four years after Beijing was chosen as the host city, in the year of the event and in the four years after it. It was possible to conclude that investment in transport infrastructure may have helped to consolidate the polycentric decentralization intended by the master plan for the city.
\end{abstract}

Keywords: Major sporting events. Olympic legacy. Host city. Urban planning. Transport.

\section{Resumo}

Os Jogos Olímpicos, ao eleger uma cidade como sede, demonstram evidência no cenário global e a concentração de investimentos no local. São realizadas intervenções urbanas que podem acelerar a realização de diretrizes preconcebidas ou redirecionar o processo de planejamento urbano. No entanto, as discussões sobre o legado de grandes eventos esportivos ocorrem em sua maioria sem estudos empíricos. O objetivo deste trabalho foi analisar as intenções de planejamento propostas e o processo de consolidação física na cidade de Beijing, China. Uma metodologia indireta de análise foi elaborada com a utilização de imagens aéreas, visando uma comparação temporal das configurações físicas no entorno das estruturas de transporte metroferroviário, identificando dinâmicas diferenciadas no anúncio da cidade como sede, no ano de realização do evento e após 4 anos. Concluiu-se que o investimento em infraestrutura de

YY is PhD in Urban Management, e-mail: yumiy@utfpr.edu.br

JT is master in Urban Management, e-mail: julianahbtomaz@gmail.com 
transportes pode ter auxiliado na consolidação da descentralização policêntrica pretendida pelo plano diretor para a cidade.

Palavras-chave: Grandes eventos esportivos. Legado olímpico. Cidade sede. Planejamento urbano. Transporte.

\section{Introduction}

The competition to host the Olympic Games (OG) represents an important opportunity for the chosen city to enjoy a greater presence on the global stage. The local government comes under pressure to increase its marketing and promotional activities and make physical and economic changes to attract investments, leading to symbolic reconstruction of the city.

The staging of major sports events provides an opportunity to make rapid urban transformations because of the availability of both public-sector and private-sector funds. Poynter (2008) notes that assessing the effects of mega events such as the OG is a complex task as the costs and social benefits for the host city are difficult to estimate. However, many cities that host the OG are not able to transform this temporary media exposure and the significant amount of funds available into something that is locally both positive and long-lasting. For citizens, the most important thing is how the funds were used and what benefits they will bring in the long term. In this context, the way in which interventions in the urban space are carried out has a significant impact socially.

In spite of this, few studies have investigated the results that the OG produce in host cities in terms of urban improvements, particularly physical ones. The city analyzed in this case study was Beijing Organising Committee for The Games of The XXIX Olympiad (BOCOG, 2008) as it was the city that invested most in infrastructure. Once Beijing had been chosen as the host city for the 2008 OG, the authorities drew up a master plan in 2004 that not only addressed the requirements laid down by the International Olympic Committee (IOC) but also included guidelines to ensure that the legacy of the Games was a long-lasting one.

The aim of this article was to identify the physical dynamics of this OG host city resulting from improvements in the urban rail network by analyzing how these improvements helped to redirect city planning. The study focuses on the physical works for the OG that sought in some way to transform the broader urban environment rather than merely the venues where the competitions took place.

Although measurement of the legacy in Beijing was limited to four years, this was sufficient to observe the impact of the OG given the rapid pace of economic and morphological change in the city. China as a whole has been expanding rapidly, with growth rates higher than those in developed Western economies. Had the analysis been carried out over a longer period after the event it would not have been possible to identify the impact of the OG as, just as occurred in Barcelona in 1996, a significant number of interventions were carried out after the event and these would have compromised the analysis.

To analyze whether the substantial investments in the urban rail system were successful in consolidating the 2004 Master Plan, it is important to understand how the urban layout of Beijing evolved over time, as it suffered significant political influence. According to Holanda (2011, p. 21), "[...] if conventions are not recognized, neither the meaning nor the configurational implications are fully interpreted".

\section{The urban layout of Beijing in context}

In the 1960s the Communist Party decided that the administrative capital of the New China would be Beijing and that it should be transformed into a productive city rather than a consumer one as there were known to be important springs and mineral resources there (Friedmann, 2005). Fifty years later, the level of industrialization in the capital is reflected in the variety and extent of its manufacturing industry: China 
divides its industrial sectors into 130 different categories, of which 120 are found in Beijing. Heavy industry accounts for $63.7 \%$ of the city's economy (Wang, 2011).

While industrial growth was the central authorities' main concern, issues related to housing were largely neglected. Policies governing property ownership underwent dramatic changes, and private property was confiscated as part of a nationalization process that lasted until 1978 (Greco \& Santoro, 2007). In that same year, permission was granted to build residential units on private property, leading to a major increase in housing density in central areas. Hutongs, neighborhoods with single-story houses and narrow pedestrian alleys, blocked thoroughfares and occupied public areas. Urban expansion occurred as a disorderly sprawl in all directions (Greco \& Santoro, 2007).

Under the command of Deng Xiaoping, reforms aimed at opening up the domestic market to the outside world were introduced in 1978. So that these reforms would not face resistance, the authorities formulated progressive narratives revolving around the notions of union, evolution from a position of subordination to one of independent development and a transition from relative isolation to inclusion in global flows (Rong, 2006). These campaigns resulted in a significant increase in the urban Chinese population. In 1949 the urban population accounted for $10 \%$ of the total population, and by 1999 this figure had reached 36\% (Friedmann, 2005).

In 1980 there were more than 14,000 chimneys in Beijing, and air pollution affected a large proportion of the population (Wang, 2011). In 1983 the Central Committee of the Chinese Communist Party recommended that manufacturing activities in the city be phased out and that the city redirect its efforts toward becoming a political and cultural capital in order to attract tourists. Measures were approved that prioritized conservation of historic sites in the central area, such as the designation of listed buildings and introduction of height restrictions.

In 1999 the municipal authorities decided to move 134 factories that were a source of pollution to outside the city walls by 2004. Over half the companies in Beijing are located in the old central area. This measure appears to have been influenced by the preparations for the 2008 OG. The urban transformations that occurred in Beijing over the centuries have left their mark on the city's current layout and can be summarized as follows: the central area of Beijing, where the old capital is located, was founded in 1267 and retains its original characteristics, including a dense street gridiron based on a central axis and rectangular blocks. The second ring follows the layout of the city walls, which were demolished in the 1950s, and has at its center the Imperial Palace opposite Tiananmen Square. A north-south axis and an east-west axis separate the four districts, as shown in Figure 1 (Greco \& Santoro, 2007). 


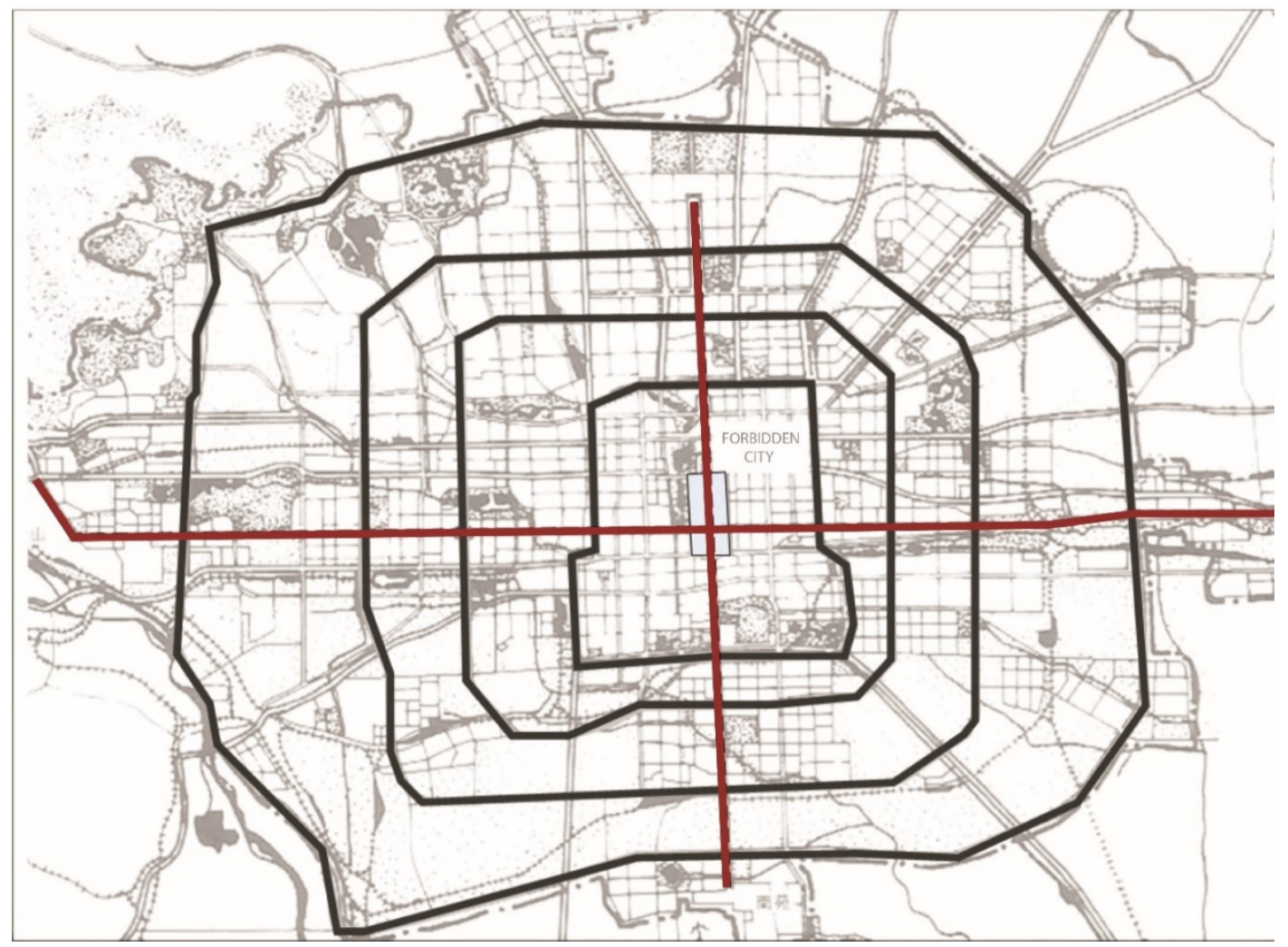

Figure 1- Beijing road plan - 1982. Source: Wang (2011).

This planning of the road system with constant reference to the center, where political power is located, has been the underlying principle determining the evolution of the city. The 1992-2010 Regulatory Plan provided for conservation of the historic center and controlled growth of sequential rings concentrating most of the state's investments, while the outskirts would be redeveloped with the aid of private investment (Greco \& Santoro, 2007). This led to a fragmented spatial configuration and a mixture of incompatible uses side by side.
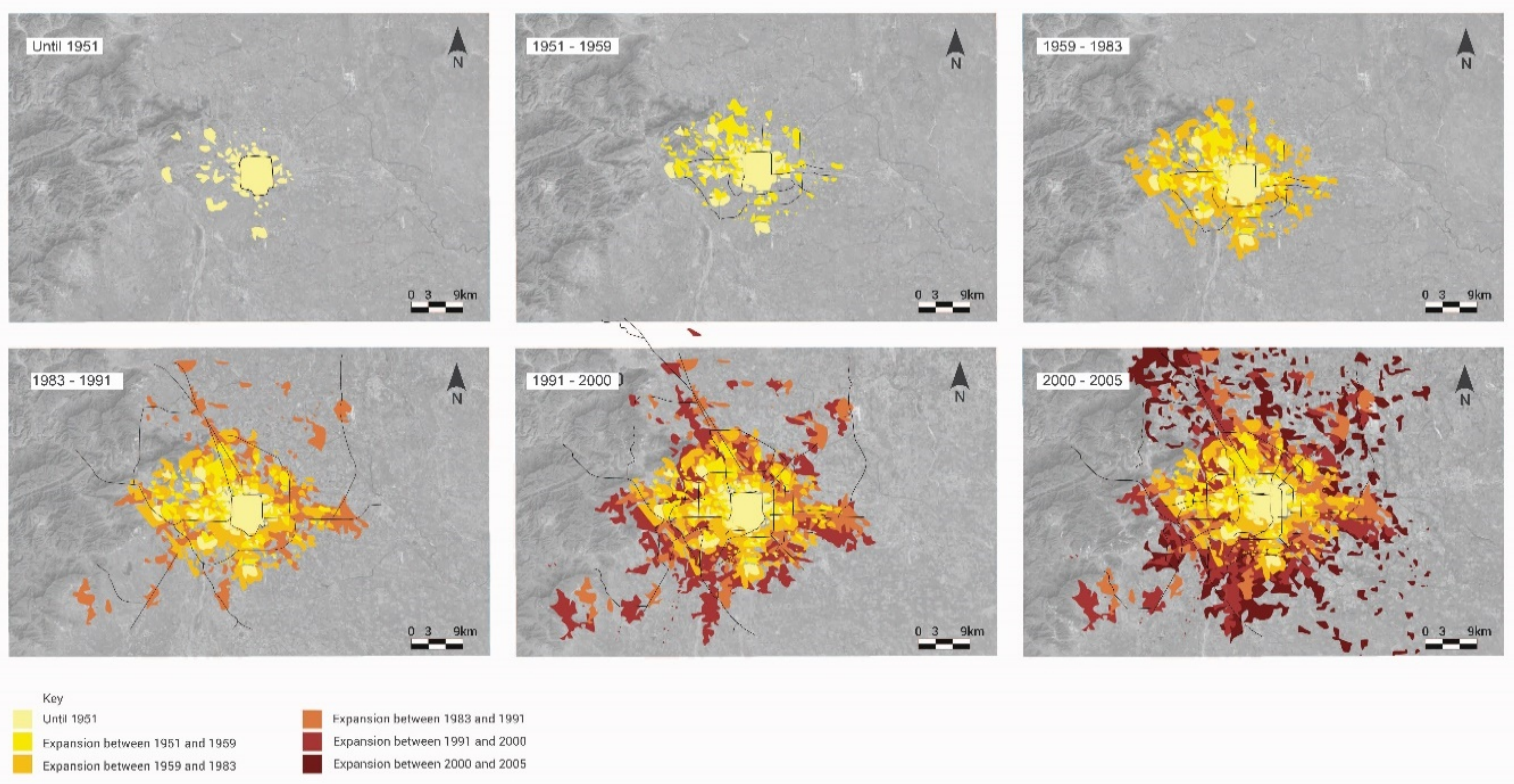

Figure 2 - Urban expansion of Beijing in the period 1951 to 2005. Source: adapted from Wang (2011), Huang et al. (2008), and the Google Earth cartographic base. 
The Beijing urban area grew rapidly, as shown in Figure 2. By 1994 it extended over an area equivalent to that forecast for 2006, and the population was 5.27 million, the figure estimated for 2010 (Wang, 2011). The preparations to host the OG in accordance with the IOC's requirements involved making significant changes in the city as a whole and provided an opportunity to reformulate the existing plan.

The 2004-2010 Master Plan provided for an ecological belt and a development belt: the eastern section would be reorganized along environmental lines, and the western section would be planned as a production zone (BICP, 2010; Song et al., 2006). The plan was intended to encourage the development of a multicenter system made up of Special Economic Zones (SEZs), as shown in Figure 3: Haidian Development Zone; the Central Business District (CBD); Sanlitun District; the Airport Line Zone; the Historic Center; and the Olympic Green (OGN).

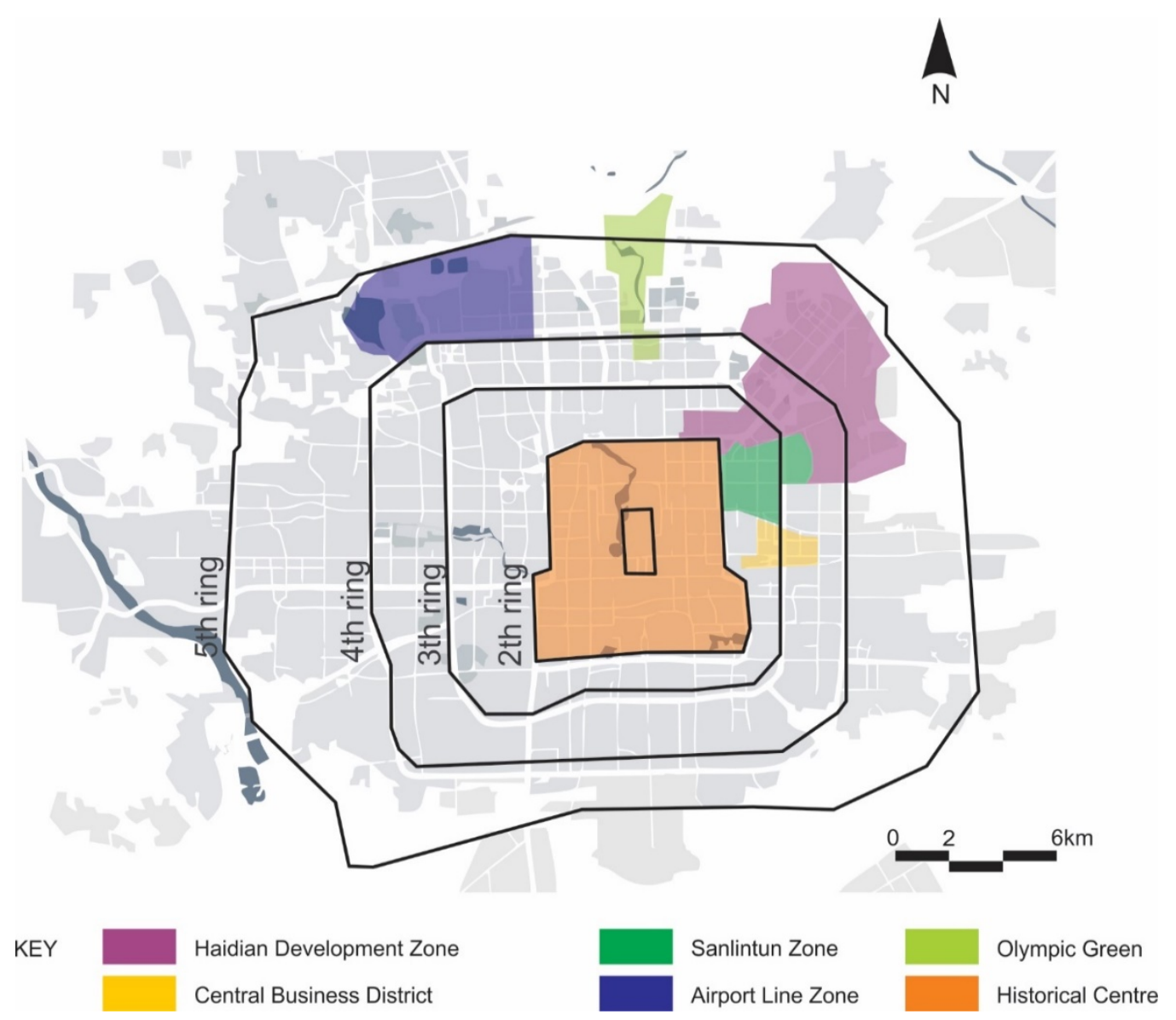

Figure 3 - Beijing Special Economic Zones. Source: Greco \& Santoro (2007).

The CBD and OGN were inspired by Western trends and sought to increase trade with member countries of the World Trade Organization. The authorities hoped to attract foreign businessmen to China with the introduction of various multifunctional complexes. Unlike Western CBDs, where there are only businesses, the CBD in Beijing would be mixed use, like other development zones in the city, so that the population working in the zone could also live and consume there, making it self-sufficient. This area was occupied by major multinationals, in offices next to the Forbidden City (Greco \& Santoro, 2007) and is characterized by densely packed skyscrapers with more than 30 floors.

The area between the CBD and the airport is known as Sanlitun District, a luxury residential district that is home to embassies and tourist bars. Soviet-style residential buildings with six floors have been replaced by tall towers and modern shopping malls. The express road corridor connecting the center of Beijing to the airport is the most advanced in the city. The historic center, which best reflects the city's identity, now has two thirds fewer old alleys and houses with internal courtyards than in the 1960s (Yukata, 2004). 
During the preparations for the OG, the planning bodies in the various districts started approving large parks and shopping areas, widening and paving roads that were a priority for the event, installing street lighting and setting up advertising displays to make the city more attractive for foreign tourists (Pitts \& Liao, 2009). The SEZ known as Olympic Green, where the most important interventions for the 2008 OG were carried out, was used for agricultural purposes until it was modernized in the 1990s, when the $11^{\text {th }}$ Asian Games were held there and a center for international congresses, three stadiums and various hotels, parks and museums were built (Greco \& Santoro, 2007).

The Beijing authorities proposed that a specific park be constructed for the event and concentrated most of the competitions in a single space. The idea of transforming the area into a central focal area required that the authorities draw up a program to review the existing infrastructure and transport services, reforest large areas that would be used as parks, refurbish existing buildings and build new ones.

The 2004 Master Plan showed that the city attributed less importance to the Olympic Green (OGN) than previous host cities, which considered the Olympic Park the main urban intervention during the preparations for the Games. Hence the OGN's position in the north of the city, close to universities, the airport and other SEZs, where it could help to ensure that the plan to decentralize Beijing was a success.

Unlike host cities such as Barcelona, which separated the sports facilities in order to make improvements in the city as a whole, Beijing, because of its very scale (Greater Barcelona covers $3,236 \mathrm{~km}^{2}$, while Greater Beijing extends over $16,807.8 \mathrm{~km}^{2}$ and the large distances separating the facilities, which would not meet IOC standards, was not able to use the same approach. The local authorities in Beijing therefore chose to concentrate the sports facilities in one location. Beijing was the host city that invested most in infrastructure.

According to Pitts \& Liao (2009), by concentrating sports facilities on the outskirts of the host city, the Olympic Park can be built on a large piece of land and there tend to be fewer negative consequences for the surrounding areas because of the low population density. However, if large numbers of tourists are to visit a single venue on the outskirts of the city, then suitable infrastructure, particularly transport facilities, must be provided. Beijing was the host city that invested most in infrastructure.

\section{Material and methods - Consolidation of the multicenter configuration}

Urban expansion in Beijing, which has traditionally occurred around a single center, has recently become regional in scale and has started to affect access to the central areas. Because of this, the city authorities proposed a multicenter configuration in which each zone was oriented toward specific use so that the different SEZs did not compete with each other.

To analyze the extent to which this plan has been successful, the impact of the expansion of the urban rail network on the urban dynamics was investigated, as this was considered a proxy for measuring the effectiveness of the plan since it attracts large numbers of people and modifies the city's configuration.

The first subway line was built in 1965 for military purposes following the deterioration in relations with the Soviet Union, with which an armed conflict was increasingly likely. Although completed in 1969 and brought into operation in 1971, part of the present Line 1 underwent various changes and expansions and was only opened to the public in 1981. During this period, migration from the countryside to urban areas was increasing. Migrants from the countryside settled in poor-quality housing in the suburbs because of the low rents. The monocentric structure persisted for cultural and market-related reasons as the new population had to travel to the center, the main productive area in the city (Huang, 2004; Song et al., 2006).

The significant urban expansion from the 1990s onwards led to a lack of integration between transport planning and land use. The sprawling urban growth that now characterized the city meant that urban mobility was dependent on private transport (Huang, 2004). Consequently, the main roads were 
frequently congested, obliging the authorities to build five other ring roads by 2008 . On some lines, buses took four times the normal time (160 min vs. $40 \mathrm{~min}$ ) to cover the route (Wang, 2011).

Faced with this situation, which spoke against the city that sought to host the 2008 OG, a new Master Plan (Beijing City Master Plan 2004-2020) was approved (Huang, 2004; Li et al., 2005; Song et al., 2006). Beijing planned to expand its urban rail system by $87.1 \mathrm{~km}$, to cover a total of $200 \mathrm{~km}$. Although expansion of the system had been included in the financial package for the OG, only some of the lines would serve the locations where the events were to be held, as the rest of the lines would go to other parts of the city, particularly the south, to support transit oriented development (Pitts \& Liao, 2009).

According to the Beijing Organizing Committee for the Olympic Games (BOCOG, 2008), the expansion of the urban rail system planned for 2008 would serve $80 \%$ of the sports venues during the OG. Unlike most of the cities that hosted the OG (Sydney, Atlanta and Athens), where transport was geared toward a temporary system for spectators (500,000 to 700,000), athletes and organizers, Beijing introduced a permanent system that would support the long-term urban transformations planned for the city.

In 2001, before Beijing had been chosen as the host for the 2008 OG, there were only two lines, both in the central district. For the 2008 OG the network was extended by some $143.61 \mathrm{~km}$ and the rolling stock was increased to 1,420 vehicles, bringing passenger capacity to between 150,000 and 200,000, in line with the IOC requirements, as shown in Figure 4 (BOCOG, 2008).

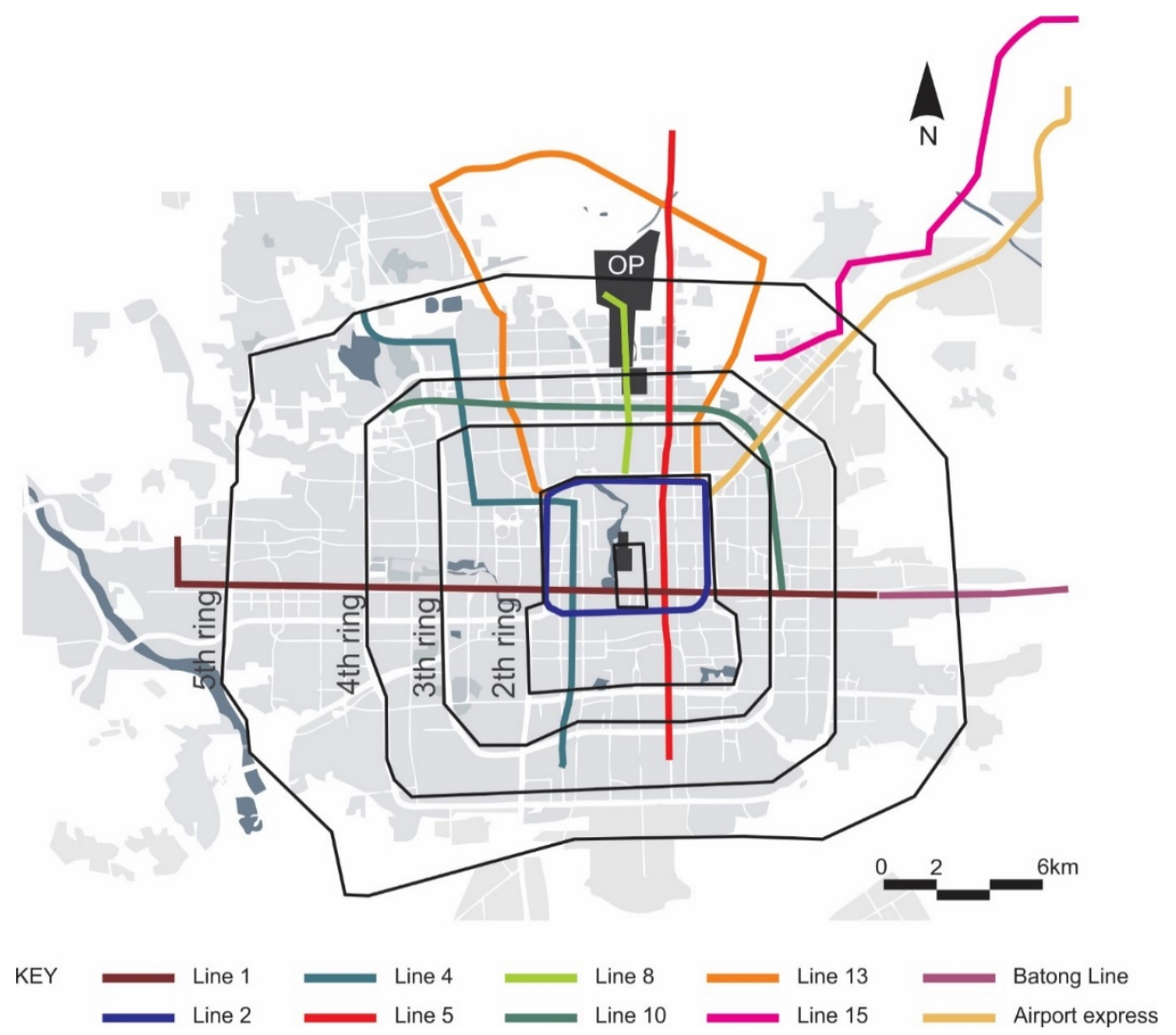

Figure 4 - Beijing urban rail network in 2008. Source: BOCOG (2008); Li et al. (2005); Greco \& Santoro (2007); and $\operatorname{BICP}(2010)$.

To determine whether the urban rail network helped to increase the physical dynamics of Beijing in the SEZs established in the 2004-2020 Master Plan, we chose to perform a spatial analysis of the stations in the SEZs as the dynamics of land occupancy are to a large extent determined by users of public transport who want to live or open a business near these stations. These are the people who establish the relationships between the urban rail network and the surrounding areas.

The rail lines were drawn on aerial photographs taken in 2001, 2004, 2008 and 2012 and the locations of the stations on the lines were marked. To analyze the extent to which the transport system contributed 
to the dynamics, the urban rail network was superimposed on the areas that underwent modifications in each of the SEZs. In this analysis we included areas where buildings had been knocked down, had been built, were being built or had been modified during the study period without making any distinction between them. These areas are shown in red in the maps below. The images used for this purpose were taken from Google Earth.

The study period was chosen so as to identify whether the changes were more significant during the period following the announcement that Beijing was to host the event (2001-2004), during the four years prior to the event (2004-2008) or during the four years following it (2008-2012). The rail lines are shown as either dotted lines (indicating that they were still being built) or solid lines (indicating that they were operational and being used by the public).

According to Torrens \& Alberti (2000), 40 to $45 \%$ of rail users live up to $800 \mathrm{~m}$ from a station. Circles with this radius were therefore defined around all the stations, as any changes within these are more likely to be directly related to the presence of the subway lines.

In the case of the OGN, which was specifically planned for the OG, a second polygon was added. As changes in this zone between 2001 and 2008 were related exclusively to the event, analysis of the dynamics in this area would indicate not spontaneous occupation but occupation driven by the local authorities. To analyze the impact of the interventions for the OG on the area surrounding the OGN, an area extending two blocks beyond the edge of the OGN was defined and the dynamics of the changes in this area were observed.

After this, it was decided to investigate the transformations in the nine stations with the largest number of arriving and departing passengers in greater detail. Of the nine stations, two were chosen because they were cited in Greco \& Santoro (2007) as being important, and seven had the greatest passenger flows. The stations were classified according to whether they were inside or outside an SEZ.

A circular coverage area with an $800 \mathrm{~m}$ radius was drawn in order to identify changes in urban land occupancy in areas close to these stations. The analysis was carried out in the periods 2001 to 2004, 2004 to 2008 and 2008 to 2012 .

\section{Results and discussion}

Between 2001 and 2004, as shown in Figure 5, the changes occurred closer to the OGN, while between 2004 and 2008, with the inauguration of subway Lines 13, 5 and 8, the interventions extended to the north. Of particular note in 2008 are the areas surrounding Lisuiqiao station (Line 5) and Licunqiao station (Line 8), as well as the three stations in the extreme north (Line 13), which also influenced the dynamics, particularly between 2008 and 2012. Line 10 contributed in a smaller way to the dynamics of the area, as can be seen from the constant small changes during the study period. To the north of Forest Park, a significant number of green areas flanked by villages in the city (illegal, densely packed buildings, usually with six floors) that are not served by any subway station. 


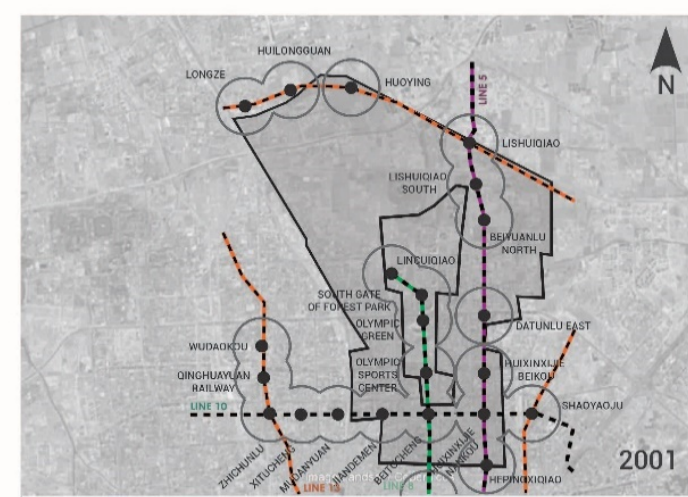

The OGN area is partially occupied by hutongs; the rest of the area is unoccupied land. In the surrounding area there are factories to the west and residential six-floor, Soviet-style blocks to the east.

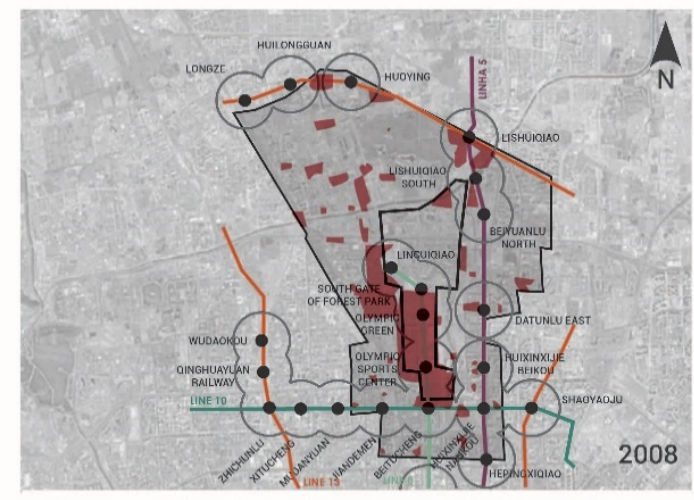

The area that has changed most is around Licuiqiao station, where the Olympic Village was built, boosting construction of residential buildings in the area.

KEY

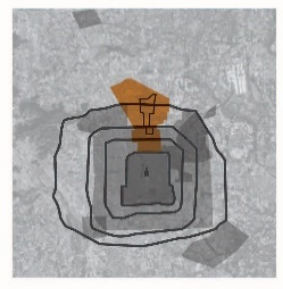

Location of the Olympic Green

Changes during the period

- Subway station

Coverage area $-800 \mathrm{~m}$ radius

--- Future subway line

$\begin{array}{cc}\text { - Line } 5 & - \text { Line } 10 \\ - \text { Line } 8 & - \text { Line } 13\end{array}$

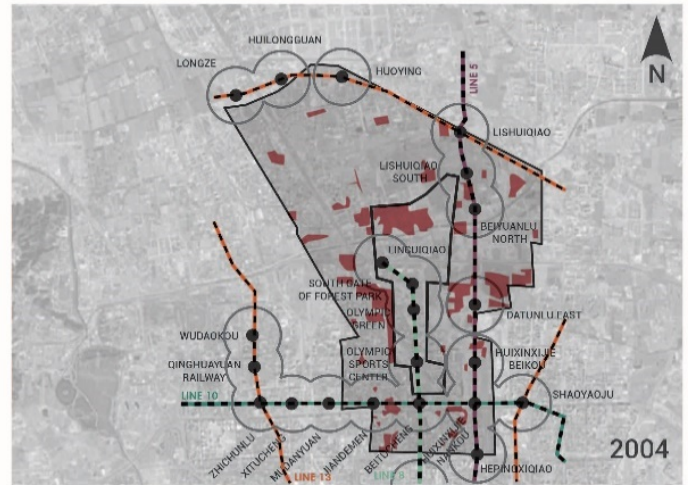

Scattered changes with the exception of the area along the western edge of the $\mathrm{OGN}$, which is closer to the center of the city and where tall residential blocks have been built.

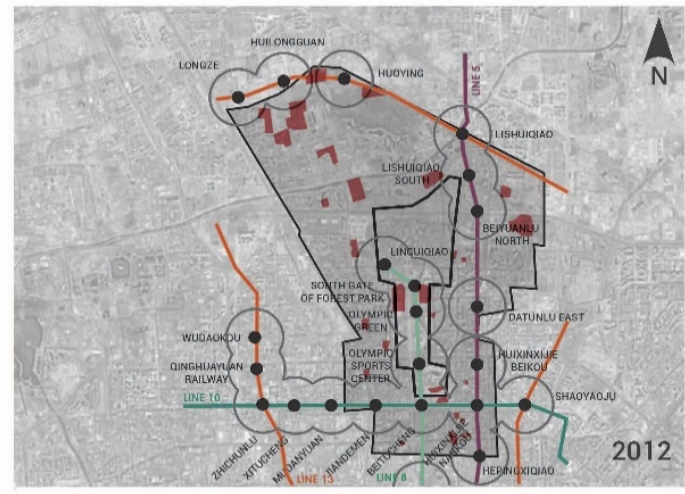

The surrounding area has continued to change although the percentage of the overall area that has changed is lower.

Figure 5 - Physical dynamics of the coverage areas of the subway stations in the Olympic Green Zone in 2001, 2004, 2008 and 2012. Source: the author, 2013, and Google Earth cartographic base.

Although the Airport Zone is defined as an SEZ, not very many subway lines go through it, as shown in Figure 6. Only the Airport Express, which does not have any intermediate stations between Dongzhimen station (outside the SEZ) and the airport, cuts through the zone. Lines 10 and 15 pass through the edges of this zone, and it is precisely in these areas that a greater number of changes can be observed. The fact that the SEZ is poorly served by the subway makes access to the area difficult, preventing it becoming established as a central focal area. Because of this, higher population densities were observed in the western sector close to the OGN. 


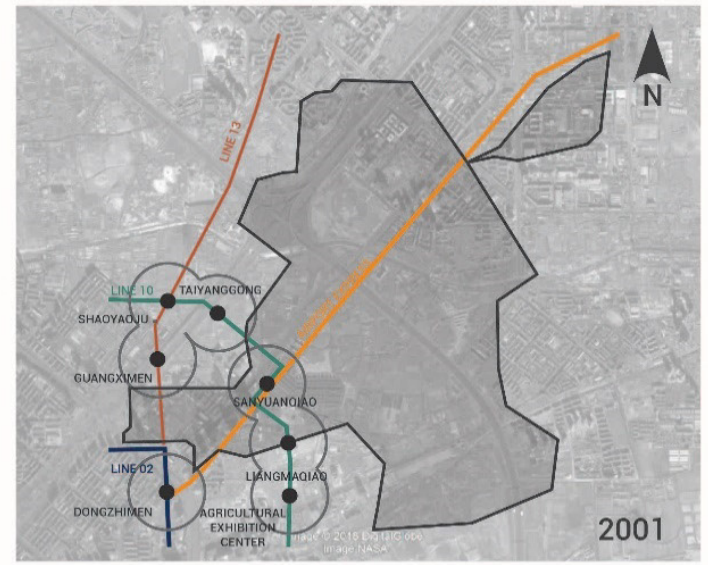

A sparsely occupied area, large areas without any buildings and clusters of hutongs and residential buildings.

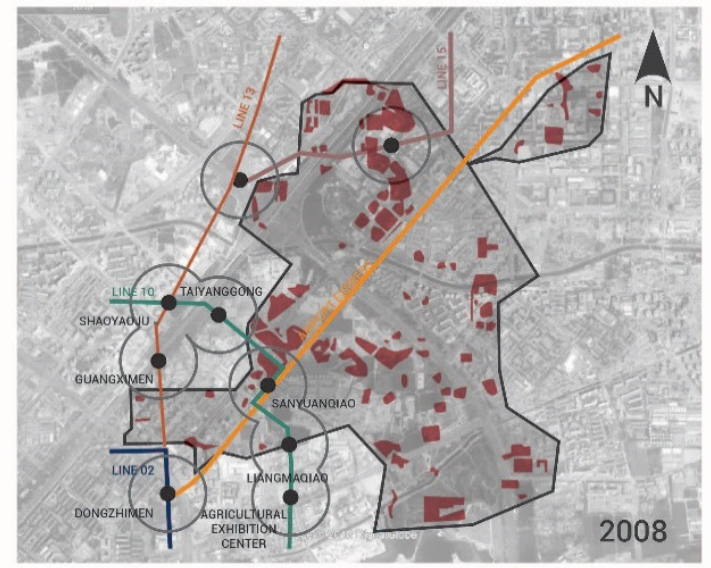

Although there have been changes throughout the sector, these are particularly noticeable in the areas around Wangjing and Wangjing West stations (Line 15) and between Tayanggong and Saniuyanqiao stations (Line 10).

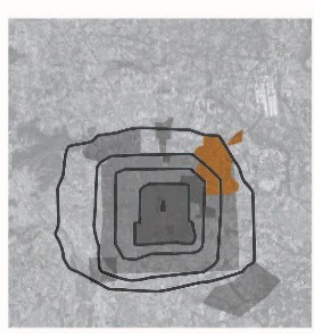

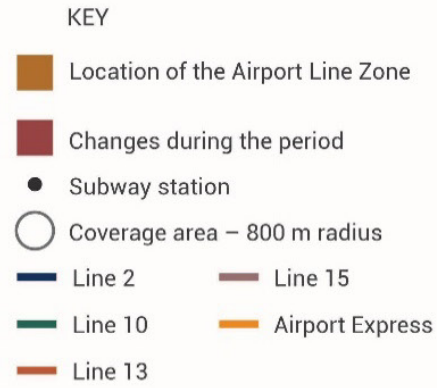

Figure 6 - Physical dynamics in the coverage area of the subway stations in Airport Zone 1 in 2001, 2004, 2008 and 2012. Source: the author, 2013, and Google Earth cartographic base.

As the Historic Center has the most infrastructure in the city, the extensions to Lines 4 and 5 did not lead to concentrated changes near the stations, as shown in Figure 7. However, greater dynamics can be observed in the east between 2001 and 2003, when Line 5, which was completed in 2007, was being built. Later, changes also occurred in the west, when Line 4 was being completed. Between 2008 and 2012 there was a reduction in the dynamics in the area.

Even in an old, well-established part of the city there was significant real-estate activity in the period between the announcement of Beijing as the host city and the staging of the OG, probably because of the government's efforts to promote urban interventions aimed at making the city more appealing to foreign tourists attracted by the event. 


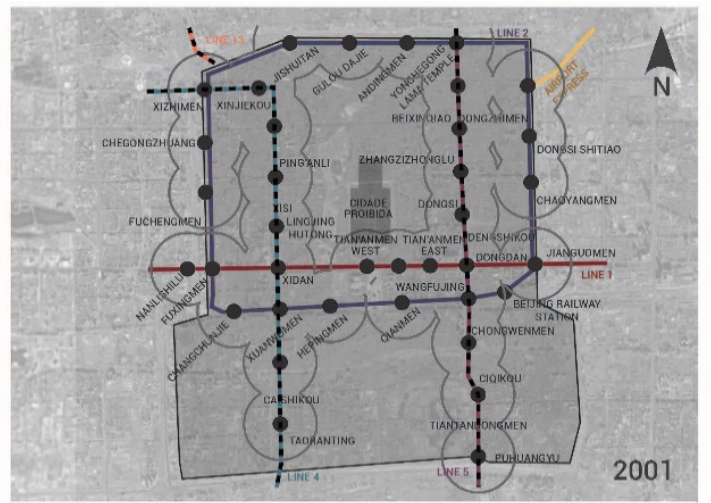

The area benefits from being served by the only two subway lines in Beijing.

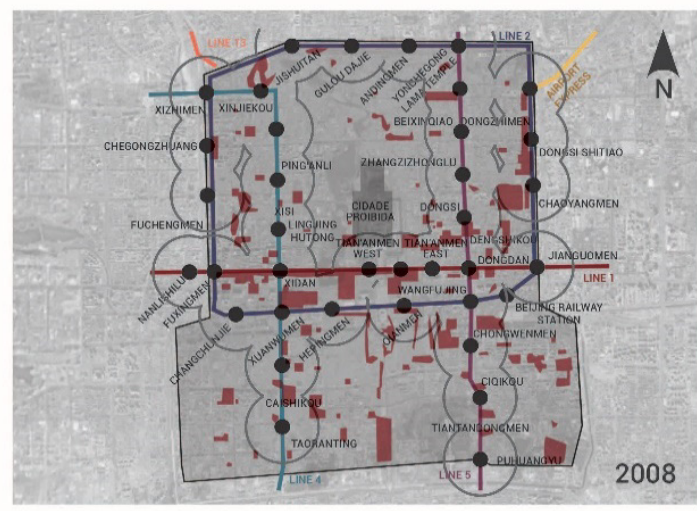

With the completion of Lines 5 and 4 there have been changes in the middle of the sector, but there has not been a significant increase in the area that has changed.
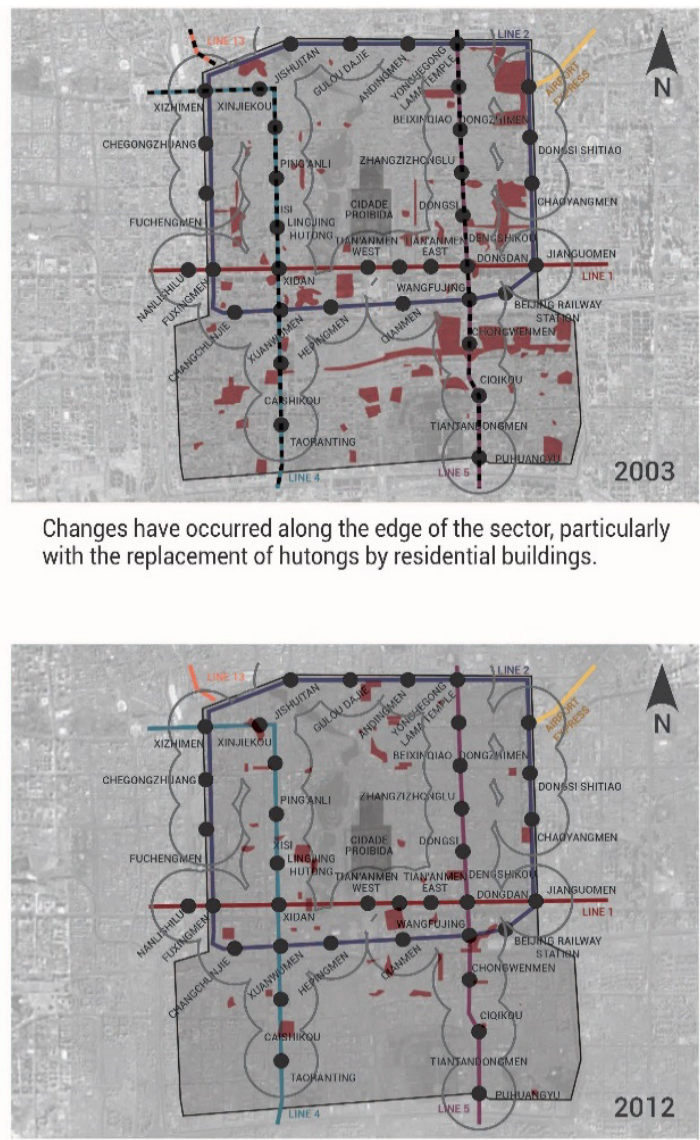

There have been fewer changes.

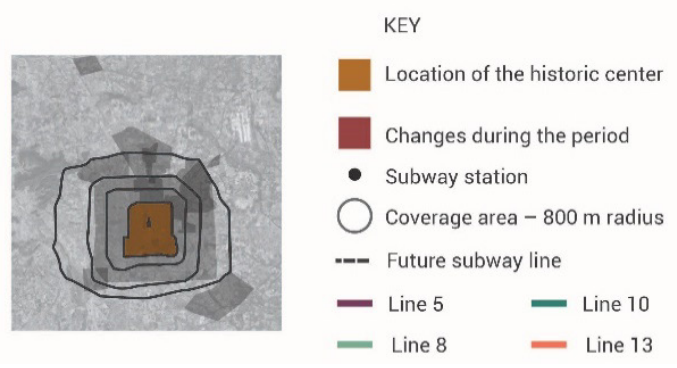

Figure 7 - Physical dynamics in the coverage area of the subway stations in the Historic Center in 2001, 2004, 2008 and 2012. Source: the author, 2013, and Google Earth cartographic base.

In the Haidian SEZ the period following the announcement that the OG would be held in Beijing (20012004) was the most dynamic, as shown in Figure 8. The changes occurred independently of the introduction of the subway lines, for which planning and construction only started in 2004. The emergence of high-quality buildings in the west, closer to the OGN, may have been a result of the facilities planned for the event. This type of occupancy increased steadily between 2008 and 2012 even without any stations along Line 13 , indicating that the population living in this area may not be rail users.

In contrast, changes in Sanlitun occurred more rapidly between 2005 and 2008, mainly within the coverage areas of the stations on Lines 10 and 2, as shown in Figure 9. The exception to this was the buildings in the west of this sector alongside Chaoyang Park next to the developments for the OG, which were being completed during that period. 


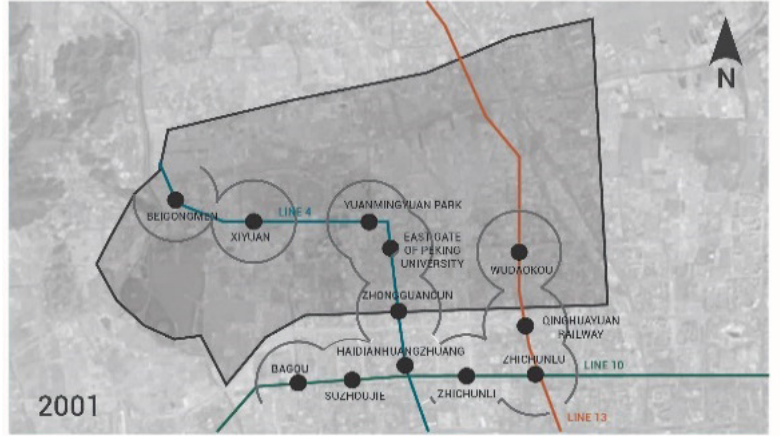

The area is home to two of the most important Chinese universities, yet it is not served by the subway.

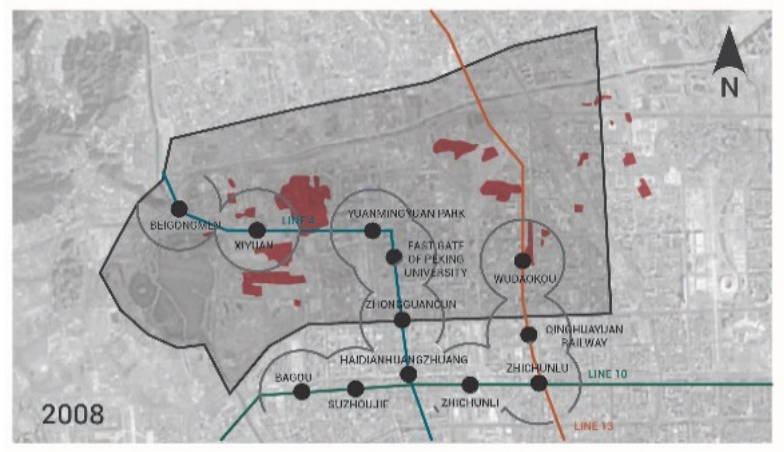

Changes have become more noticeable around Xiyuan station, where VICs have been replaced by gated communities.

$$
\text { KEY }
$$

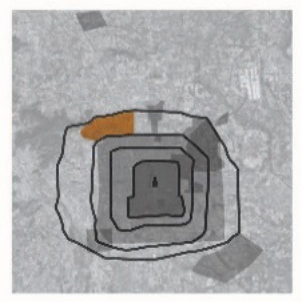

Location of Haidian Special

Economic Zone

Changes during the period

- Subway station

Coverage area $-800 \mathrm{~m}$ radius

- Line 4

- Line 10

- Line 13

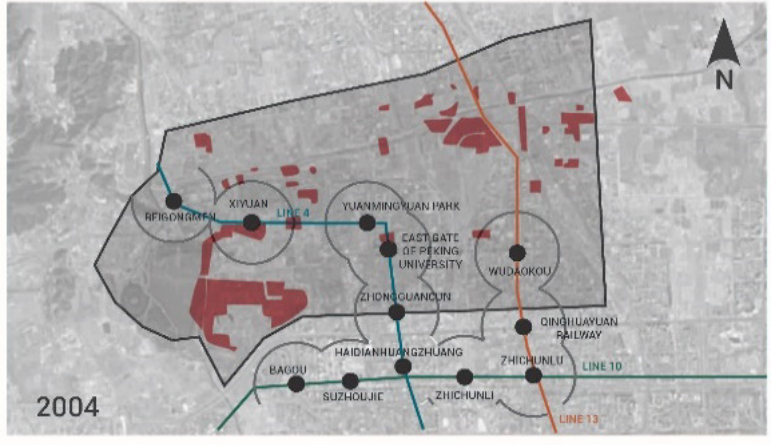

The beginning of the works for Line 4 has produced changes, particularly in the area around Xiyuan station. The area between Lines 4 and 13 is occupied by Tsinghua University and is therefore more stable.

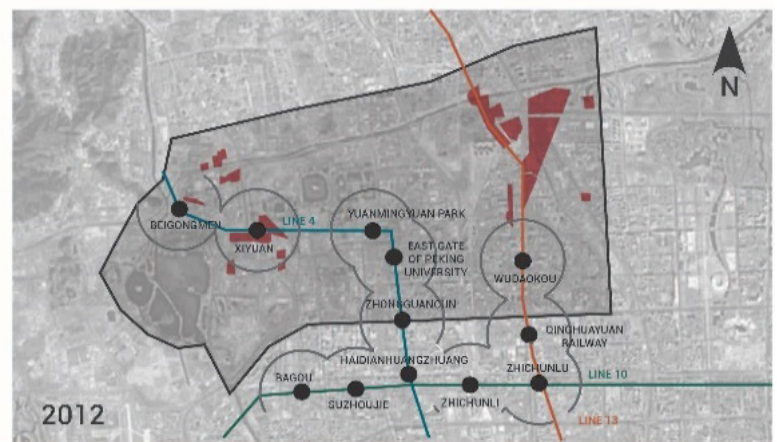

Changes have become more noticeable near Line 13, with buildings and houses in wooded areas.

Figure 8 - Physical dynamics in the coverage area of the subway stations in the Haidian Special Economic Zone in 2001, 2004, 2008 and 2012. Source: the author, 2013, and Google Earth cartographic base. 


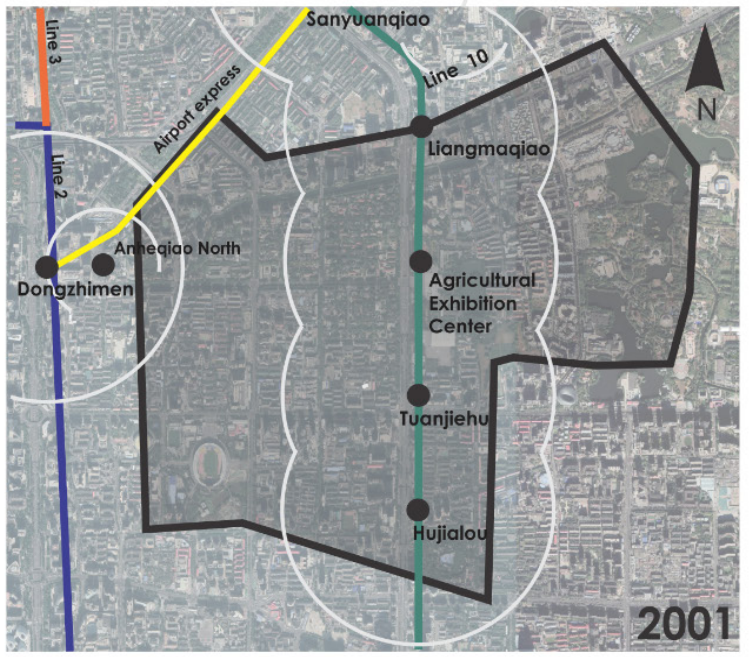

Although central, the western portion is unocuupied.

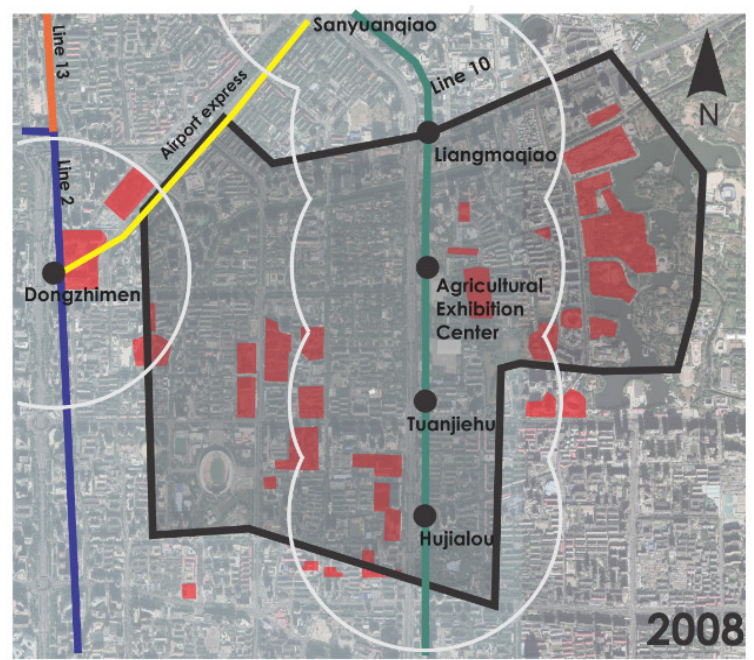

There is increased dynamics in the compartment. The east portionreplaced by mixed-use buildings. The parkChaoyang is built on the west side and the buildingsof the surroundings are to be of high luxury buildings.

Location of the Sanlitun District

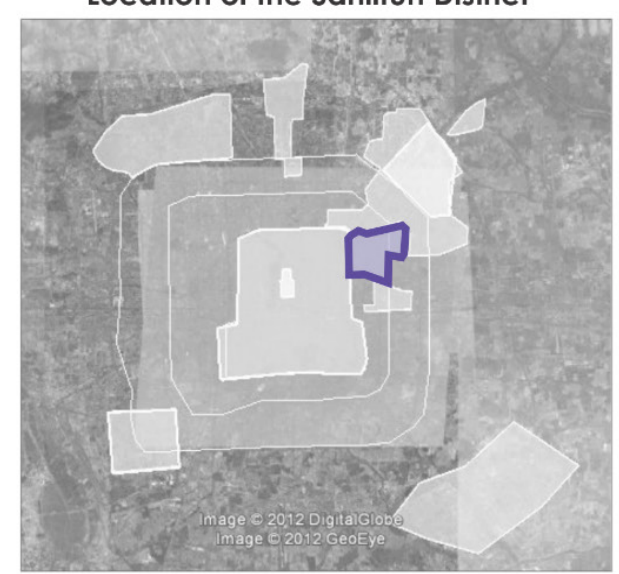

Figure 9 - Physical dynamics in the coverage area of the subway stations in Sanlitun District in 2001, 2004, 2008

and 2012. Source: the author, 2013, and Google Earth cartographic base.

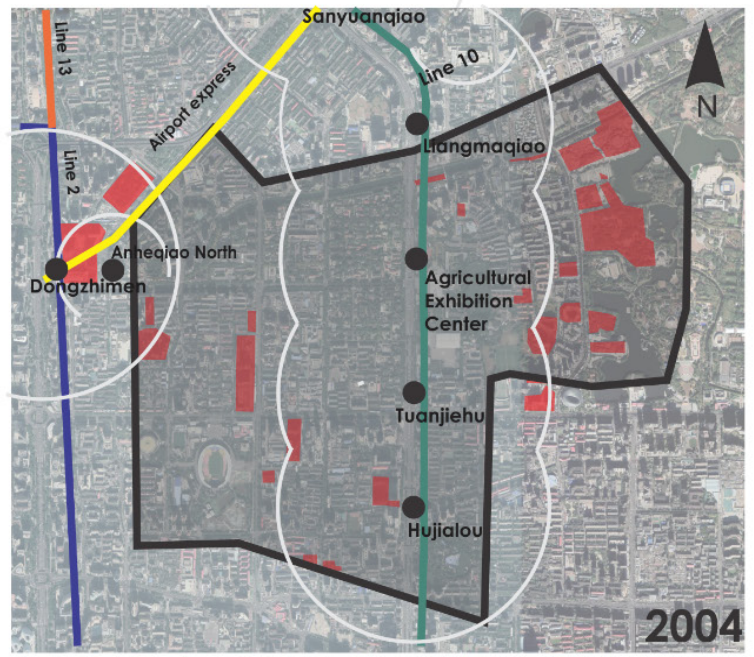

Before the construction of line 10, the distant areasof the line is that they change.The eastern portion is occupied by hutongs.

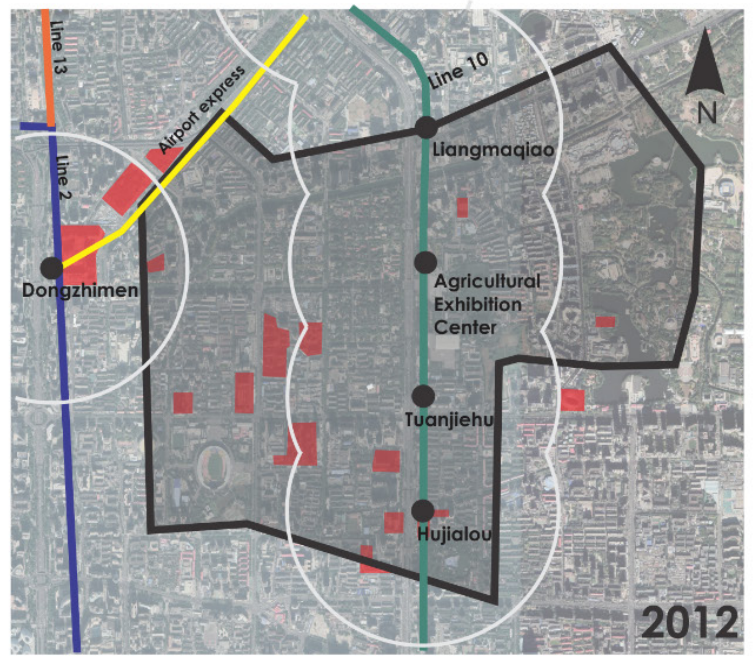

Modifications occur with demolitionof old hutongs.

\section{Key}

Changes during the period

Coverage area $-800 \mathrm{~m}$ radius

Subway station

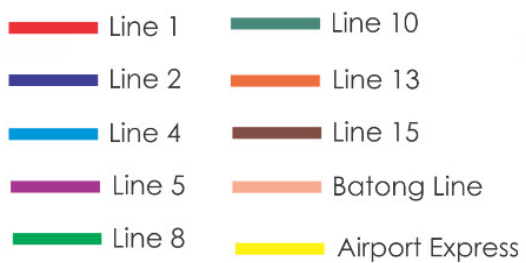


As the Central Business District, like the OGN, is smaller than the other zones, an area of influence extending two blocks beyond its boundaries was defined, as shown in Figure 10. The pictures of this zone show that the changes extend beyond its perimeter. Because this SEZ is home to the most important business center in Beijing, there have been many changes throughout the zone since 2001, which would have occurred even if the rail system had not been expanded. However, it can be seen that the development of the transport facilities resulted in an increase in the dynamics between 2004 and 2008 along two axes: east-west, along Line 1, which was already in operation, and north-south, along Line 10. The dynamics along this new line increased from 2008 to 2012.

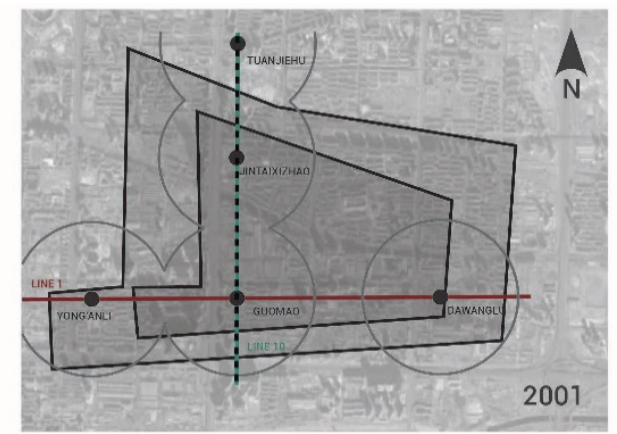

The area has many telecommunications buildings.

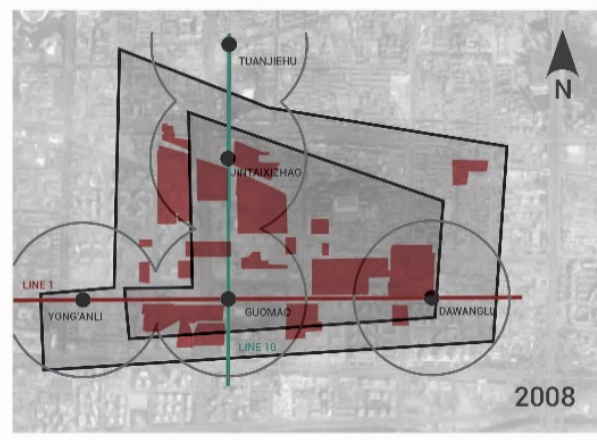

Once again the sector has been modernized and has retained its role as a center for communications, shops and services. Changes have occurred along line 1 and along the now-completed Line 10.
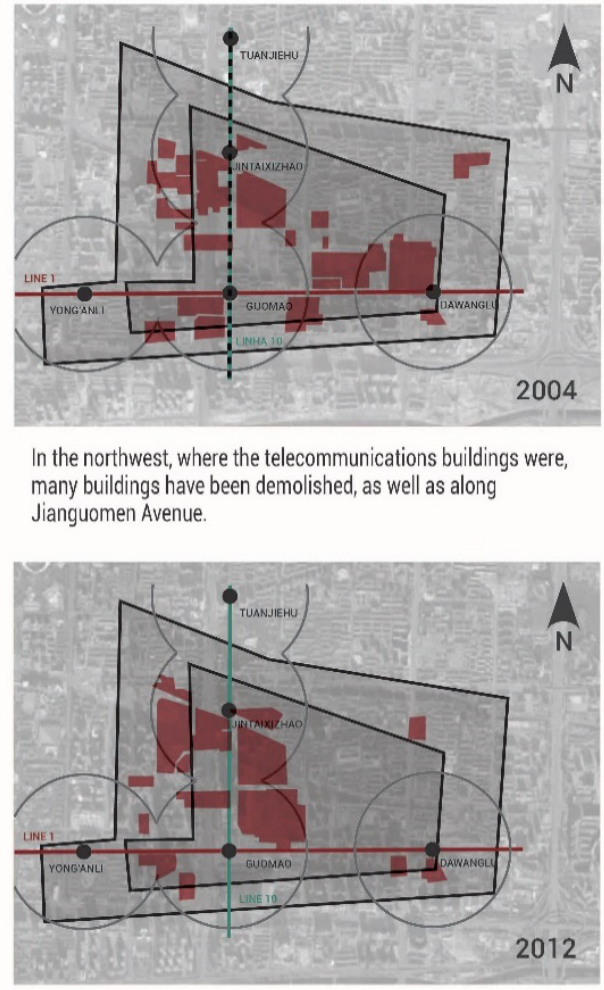

Changes have again occurred along line 10 . These include construction of the CCTV Headquarters.

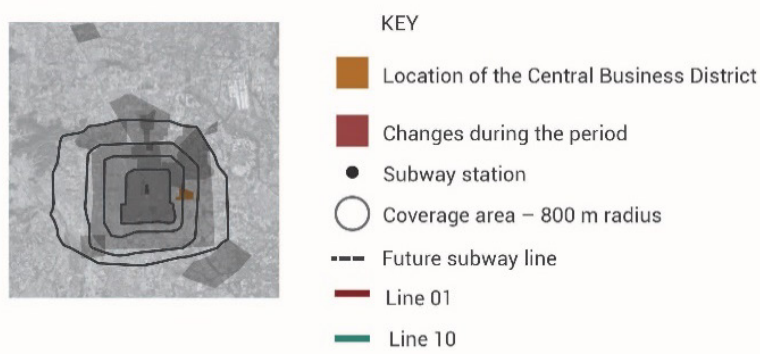

Figure 10 - Physical dynamics in the coverage area of the subway stations in the Central Business District in 2001, 2004, 2008 and 2012. Source: the author, 2013, and Google Earth cartographic base.

By superimposing the SEZs and the urban rail network, significant relationships between the dynamics of the changes in the various zones and the period when the subway lines were built could be identified. With the exception of Haidian ZES, which saw more significant growth in the period 2001 to 2004, the other zones underwent transformations between 2004 and 2008, when the subway system expanded. Significant change was observed along the lines within the SEZs. However, based on the analysis carried out in this study, it is not possible to state that these SEZs became central focal areas, as the changes were observed only within the SEZs and no attempt was made to compare each zone with 
the rest of the city. If the other areas underwent changes in the same proportions, then there was no difference in the dynamics between the SEZs. Because of this, it was decided to analyze some arriving and departing stations (Figure 11) inside and outside an SEZ, and compare the changes in urban land occupancy in areas close to these stations. Figure 12 shows an example of the graphical analysis for one of the stations. The results of the analysis of the nine stations were used to compile the information in a table.

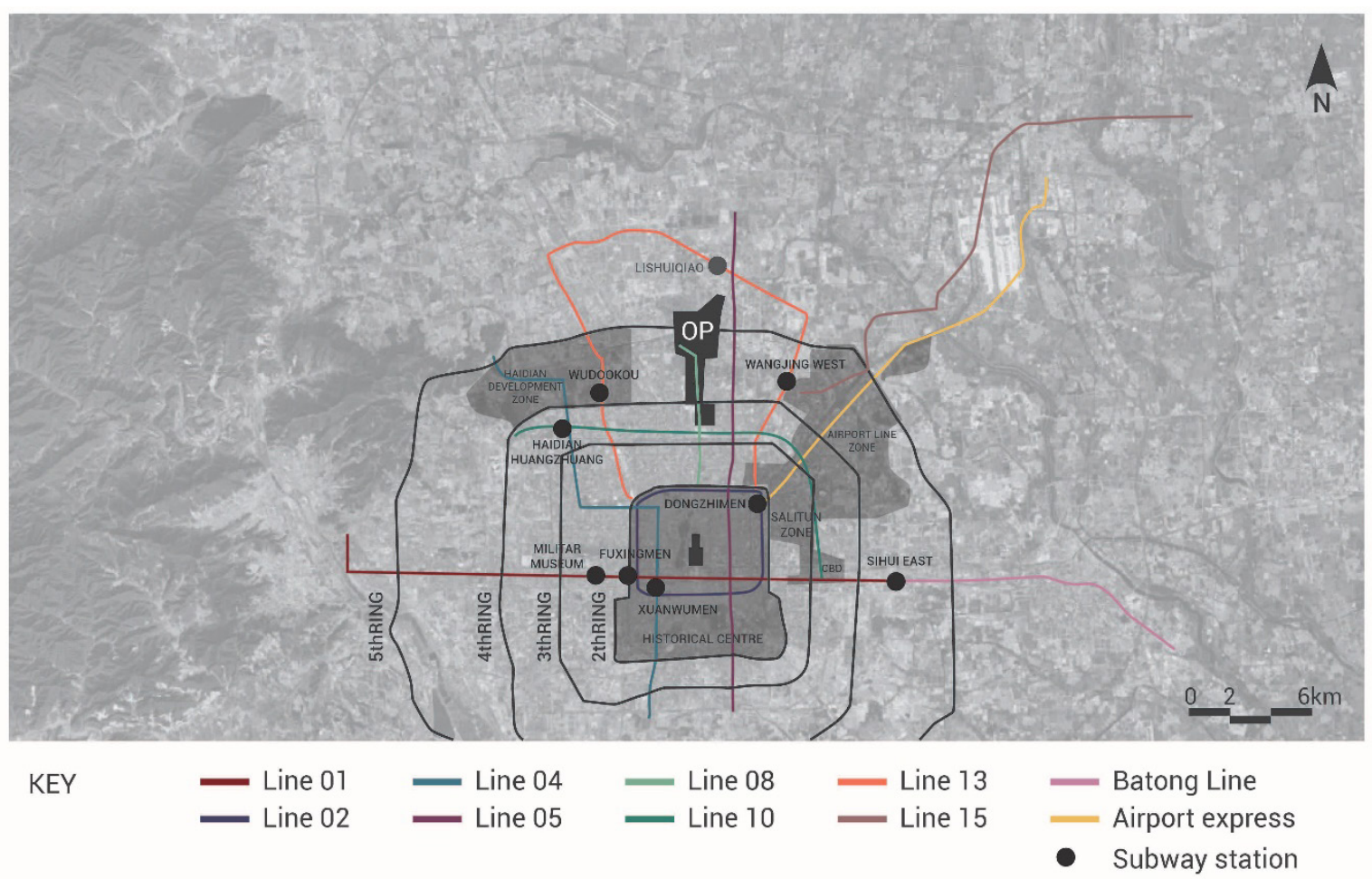

Figure 11 - Stations with the greatest number of ariving and departing passengers. Source: adapted from Travel China Guide (2013). 


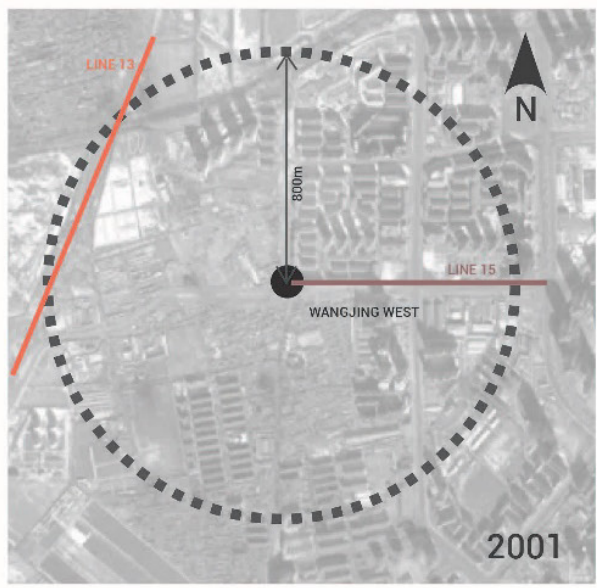

The west is densely occupied with hutongs, and the northeast with residential blocks.

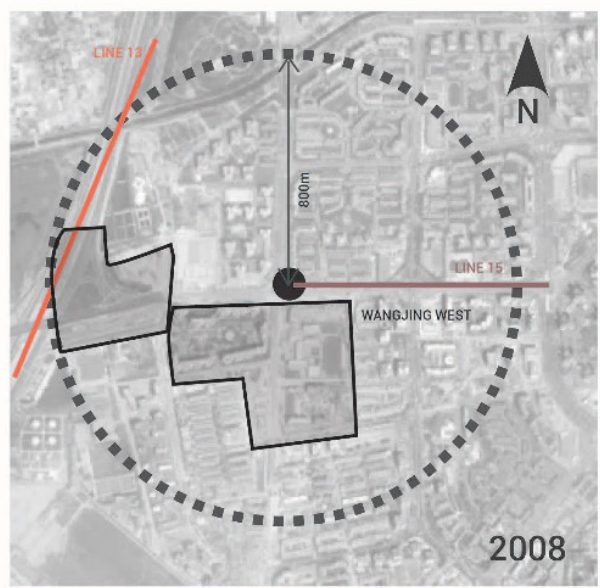

With Line 15 completed, the changes have extended toward the east.

KEY

Coverage area $-800 \mathrm{~m}$ radius

$\square$ Chandes during the period

- Subway station

- Future subway line

- Line 13

- Line 15

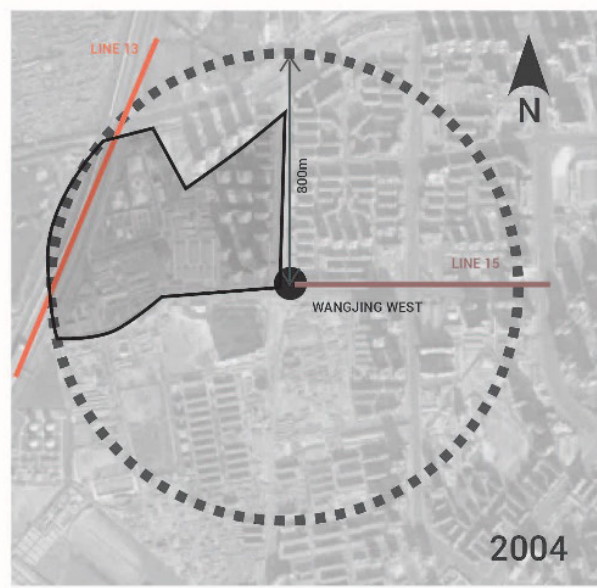

Following completion of Line 13 in 2003 , changes can be observed in the area near the line.

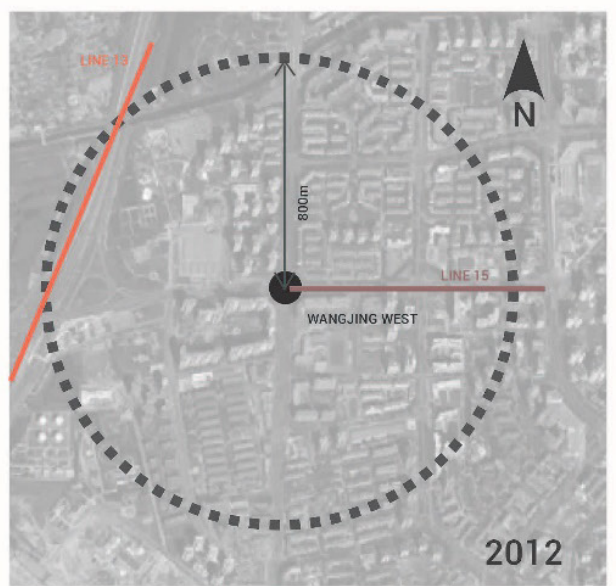

The area is now completely occupied. The new buildings are all tall buildings.

Figure 12 - Graphical example of the analysis of the dynamics in the areas surrounding the stations with the greatest number of arriving and departing passengers - Wangjing West Station - Airport SEZ in 2001, 2004, 2008 and 2012. Source: the author, 2013, and Google Earth cartographic base.

The aim in calculating the areas was not to arrive at exact figures but to compare the percentage of each area that had changed during the study periods. The darker colors correspond to the areas that changed most within an $800 \mathrm{~m}$ radius of the stations with the greatest number of departing and arriving passengers during the study period. 
Table 1 - Areas in the vicinity of the stations with the greatest number of passengers where changes were observed in the period 2001 to 2012

\begin{tabular}{|c|c|c|c|c|c|c|c|c|}
\hline & \multirow{2}{*}{ STATION } & \multirow{2}{*}{$\begin{array}{l}\text { TOTAL AREA } \\
\text { (square } \\
\text { meters) } \\
\text { (radius } \\
800 \mathrm{~m} \text { ) }\end{array}$} & \multicolumn{2}{|c|}{$\begin{array}{c}\text { constructed area } \\
2001 / 2004\end{array}$} & \multicolumn{2}{|c|}{$\begin{array}{c}\text { constructed area - } \\
2004 / 2008\end{array}$} & \multicolumn{2}{|c|}{$\begin{array}{c}\text { constructed area - } \\
2008 / 2012\end{array}$} \\
\hline & & & $\begin{array}{l}\text { in square } \\
\text { meters }\end{array}$ & $\%$ & $\begin{array}{l}\text { in square } \\
\text { meters }\end{array}$ & $\%$ & $\begin{array}{l}\text { in square } \\
\text { meters }\end{array}$ & $\%$ \\
\hline \multirow{5}{*}{ ZEE } & Dongzhimen & 2010619,29 & 757760,38 & $37,69 \%$ & 276542,73 & $13,75 \%$ & 0 & $0,00 \%$ \\
\hline & Wangjing West & 2010619,29 & 423939,44 & $21,09 \%$ & 389099,58 & $19,35 \%$ & 0 & $0,00 \%$ \\
\hline & Wudaokou & 2010619,29 & 219001,32 & $10,89 \%$ & 87912,49 & $4,37 \%$ & 132416,27 & $6,59 \%$ \\
\hline & Xuanwumen & 2010619,29 & 440687,98 & $21,92 \%$ & 0 & $0,00 \%$ & 106439,71 & $5,29 \%$ \\
\hline & Fuxingmen & 2010619,29 & 45143,89 & $2,25 \%$ & 51348,31 & $2,55 \%$ & 23954,28 & $1,19 \%$ \\
\hline \multirow{4}{*}{ OTHERS } & Lishuiqiao & 2010619,29 & 0 & $0,00 \%$ & 558779,9 & $27,79 \%$ & 152952,26 & $7,61 \%$ \\
\hline & Sihui East & 2010619,29 & 56132,68 & $2,79 \%$ & 183448,86 & $9,12 \%$ & 432460,54 & $21,51 \%$ \\
\hline & $\begin{array}{l}\text { Haidian } \\
\text { Huangzhuang }\end{array}$ & 2010619,29 & 423595,93 & $21,07 \%$ & 54365,83 & $2,70 \%$ & 0 & $0,00 \%$ \\
\hline & Militar Museum & 2010619,29 & 25576,07 & $1,27 \%$ & 129406,49 & $6,44 \%$ & 15935 & $0,79 \%$ \\
\hline
\end{tabular}

Areas classified as changed are estimates, as they were identified visually using Google Earth software. Source: the author, 2013, and Google Earth cartographic base.

The areas of the city that appear to have had the greatest change in dynamics following the expansion of the subway system were the north and east. As shown in Table 1, this could be observed in the areas served by the stations with the greatest dynamics inside the SEZs (Dongzhimen, between the Historic Center and Sanlitun District, and Wangjing West, in the Airport Zone) and outside the SEZs (Lishuiqiao and Sihui East).

The elements of the 2004 Master Plan aimed at environmental protection of the western and southern areas of the city appear to have met with success. With regard to occupancy in the outskirts, one of the factors that appears to have contributed to this was government policies that made plots of land available to the private sector only on the outskirts of the city in an attempt to increase the supply of more affordable housing.

The areas outside the SEZs were quite stable before the stations were built. With the exception of Fuxingmen, the dynamics in most of the areas in SEZs increased before the lines were built (2001-2004). This change in dynamics occurred soon after Beijing had been chosen as the host city for the OG, indicating that the resulting optimism may have had physical consequences in the city. It was not possible to establish whether there had been announcements before the lines were built that they would pass through these locations.

When the stations in the SEZs are compared with those outside these areas, a significant difference in dynamics can be observed, which may be an indication that the policy of a multicenter configuration was becoming spatially consolidated.

\section{Conclusion}

Although we measured the transformations in Beijing, the host city for the 2008 OG, it was not possible to determine whether the changes were directly related to the OG. The city that is left after the games needs to be planned so that the legacy of the $O G$, which is associated with social, economic and political factors, is a positive one. Hence, the planning intentions need to be analyzed in a local context, making it important to take into account the city's past and its culture. In this sense, being familiar with the way urban planning and the layout of the city have evolved over the years acquires particular importance.

In the case of Beijing, a positive aspect is that, unlike many other host cities, it had an existing plan for the city that was not directly related to the OG. The contribution made by the OG to consolidating the 
multicenter structure was therefore to promote public and private interest in putting the planned urban transformations into practice. This was more noticeable in terms of the economy and the media rather than the physical environment and is reflected in the analyses, which show that among the SEZs set up, those directly related to the event (Airport and OGN), had unremarkable dynamics and therefore became less established as central focal areas than the Historic Center, the CBD and Sanlitun District.

Expansion of the urban rail system played an important role in consolidating the new central focal areas, but the layout of the lines reinforces the concentric nature of the city as it encourages people to change train in the stations in the Historic Center. Nevertheless, a positive consequence of this is that the flow of people through the center helped to prevent this area becoming deserted. With the exception of Haidian ZES, which saw more marked growth in the period 2001 to 2004, the other zones underwent transformations between 2004 and 2008, when the subway system was extended.

In both cases, once the preparations for the event had started, there was a more marked increase in construction activity in the years immediately following the announcement that Beijing was to be the host city than in the year of the event itself or subsequent years. This shows that the feeling of euphoria helped to boost local economic activity, particularly activities associated with increasing real-estate prices.

Financial investments in infrastructure are known to generate benefits for the host city. For example, an improved transport system has an impact over a much wider area, as it connects different parts of the city and so ensures more egalitarian access to goods, services and jobs.

The analytical methodology used here can be justified by the fact that the relevant laws are neither widely distributed nor available for consultation. According to Chen et al. (2002), this is one of the reasons why the rules for correct land use and occupancy are not always observed. It was also for this reason that an alternative approach based on indirect indicators was adopted to investigate the extent to which the multicenter structure in Beijing had become consolidated.

\section{References}

Beijing Municipal Institute of City Planning and Design - BICP (2010). Planning and development. Retrieved in 2010, February 5, from http://http://www.bjghy.com/ghyEng/ghyEng1profile.aspx.

Beijing Organising Committee for The Games of The XXIX Olympiad - BOCOG. (2008). Official Report of the Beijing 2008 Olympic Games. Beijing: BOCOG.

Chen, J., Gong, P., He, C., Luo, W., Tamura, M. \& Shi, P. (2002). Assessment of the urban development plan of Beijing by using a CA-Based urban growth model. Photogrammetric Engineering \& Remote Sensing, 68(10), 1063-1071.

Friedmann, J. (2005). China's urban transition. Minneapolis: University of Minnesota Press.

Greco, C., \& Santoro, C (2007) Beijing: The new city. Milano: Skira editore.

Holanda, F. (2011). A determinação negativa do movimento moderno. In F. Holanda (Ed.), Arquitetura \& Urbanidade (2nd ed., pp. 19-37). Brasília: FRBH Edições.

Huang, Y. (2004). Urban spatial patterns and infrastructure in Beijing. Land Lines, 16(4), 1-4. Retrieved in 2010, June 10, from http://www.lincolninst.edu/pubs/969_Urban-Spatial-Patterns-and-Infrastructure-in-Beijing.

Huang, W., Liu, H., Luan, Q., Jiang, Q., Liu, J., \& Liu, H. (2008). Detection and prediction of land use change in Beijing based on remote sensing and GIS. The International Archives of the Photogrammetry, Remote Sensing and Spatial Information Sciences, v. XXXVII(part B6b).

Li, F., Wang, R., Paulussen, J., \& Liu, X. (2005). Comprehensive concept planning of urban greening based on ecological principles: a case study in Beijing, China. Landscape and Urban Planning, 72(4), 325-336.

http://dx.doi.org/10.1016/j.landurbplan.2004.04.002.

Pitts, A., \& Liao, H. (2009). Sustainable Olympic design and urban development. London: Routledge. 
Poynter, G. (2008). Regeneração urbana e legado olímpico de Londres 2012. In R. P. Rodrigues, L. M. M. Pinto, R. Terra, \& L. Dacosta (Eds.), Legado de megaeventos esportivos (pp. 121-152). Brasília: Ministério dos Esportes.

Rong, Y. (2006). China institute of international studies: a blue book on international situation and china's foreign affairs 2005/2006. Beijing: The Contemporary World Press.

Song, Y., Ding, C., \& Knaap, G. (2006). Envisioning Beijing 2020 through sketches of urban scenarios. Habitat International, 30(4), 1018-1034. http://dx.doi.org/10.1016/j.habitatint.2005.10.006.

Torrens, P. M., \& Alberti, M. (2000). Measuring sprawl. London: Centre for Advanced Spatial Analysis - University College London.

Travel China Guide. (2013). Beijing Subway Maps. Retrieved in 2013, January 15, from https://www.travelchinaguide.com/cityguides/beijing/subway-map.htm

Wang, J. (2011). Beijing Record: a physical and political history of planning modern Beijing. Singapore: World Scientific Publishing CO. http://dx.doi.org/10.1142/7648.

Yukata, H. (2004). Beijing Hutong Conservation Plan: The future of Old Beijing and the conflict between modernization and preservation. Tibet Heritage Fund. In cooperation with Beijing Tsinghua University. Retrieved in 2012, February 10, from: http://www.tibetheritagefund.org/media/download/hutong_study.pdf

Editor: Fábio Duarte.

Received: Feb. 27, 2018

Accepted: Jan. 27, 2019 